\title{
Aligning IT and marketing - The impact of database marketing and CRM
}

Received (in revised form): 6th October, 2004

\begin{abstract}
Kai Wehmeyer
is a researcher at the European Research Center for Information Systems (ERCIS), in Münster, Germany and an associate researcher at the Center for Interactive Marketing and Media Management (CIM), an academic institution funded by Deutsche Post World Net AG. He has studied Marketing and Information Systems at the University of Münster and is currently studying industrial and organisational psychology at the University of Hagen. He is conducting research in the fields of direct and interactive marketing, information management and multichannel management. His research interests also include organisational behaviour and change and the social impact of information technology.
\end{abstract}

\begin{abstract}
This paper discusses the conceptual differences between database marketing and customer relationship management (CRM) with a focus on the use of information technology (IT) in both practices. Practical experiences and the results of academic research are considered when Henderson and Venkatraman's strategic alignment model is applied for the identification of typical paths of alignment between marketing and IT for the two concepts. Two cases are described in order to illustrate the alignment processes. It is shown that the model is useful for further clarification of the conceptual distinctions between database marketing and CRM. The developed alignment perspectives provide an integrated view of the managerial challenges which companies face while pursuing IT-enhanced marketing strategies.
\end{abstract}

\section{Kai Wehmeyer} Department of Information Systems, University of Münster, Leonardo Campus 3, D-48149 Münster, Germany.

Tel: +49 2518338125 ; Fax: +49 2518338119 ; e-mail:

kai.wehmeyer@wi-ios.de

\section{STRATEGIC INFORMATION TECHNOLOGY PLANNING IN MARKETING}

The use of information technology (IT) in marketing is a well established topic among scholars and marketing practitioners. ${ }^{1,2}$ The concept of database marketing has existed since the 1960s and experienced a large upswing in the 1980s, when computer technology was widely adopted. ${ }^{3}$ Much later, technologically-enhanced relationship marketing, ${ }^{4}-$ customer relationship management (CRM) - had an even stronger impact on the marketing universe. In many cases, it was declared to be the remedy for a multitude of companies' problems in sales and marketing. Yet, even before the dawn of CRM, scholars and practitioners in direct and database marketing were emphasising the strategic value of IT and a customer database. ${ }^{5,6}$ The broad application of CRM systems to enable and support relationship marketing quickly lead to cases of failure, provoking more work on the problems of, barriers to, and success factors for $\mathrm{CRM}^{7-9}$ as well as critical commentaries. ${ }^{10,11}$ In particular, it has triggered a discussion which aims to differentiate between the concepts of database marketing and CRM. ${ }^{12-15}$ Oftentimes, the complexity of company-wide CRM programs and systems is in contrast to potentially simple database marketing approaches. 
Marketing management still seems to be lacking clear insights into how to leverage IT's full potential for marketing purposes. ${ }^{16,17}$

The challenge of aligning marketing needs and IT solutions both strategically and operationally has grown as IT and marketing have become increasingly intertwined. ${ }^{18,19,20}$ The marketing practice chosen by a particular company is likely to be reflected in the way IT issues are integrated into its management processes. This leads to the assumption that the two concepts, database marketing and CRM, could imply different (maybe typical) ways of managing the interplay between marketing and IT.

This paper briefly reviews the conceptual differences between database marketing and CRM and clarifies existing inter-relations. Based upon this distinction and upon documented experiences, the author applies Henderson's and Venkatraman's strategic alignment model of the marketing domain. ${ }^{21}$ Different paths of alignment for each practice are identified based on the conceptual differences and on studies discussing barriers to and drivers of their successful implementation. The model is thereby used to comprehend how the process of coordinating marketing needs and IT can take place. Database marketing and CRM are characterised by different alignment paths. The findings can further contribute to a more concrete distinction of database marketing and CRM by explicitly considering technological implications.

\section{Database marketing and CRM}

The different IT implications assumed for database marketing and CRM are rooted in the conceptual differences between them. To pinpoint these differences, one has to disengage from those voices that declare relationship building is a core functionality within the concept of database marketing. ${ }^{22,23}$ Here database marketing is understood to be IT-enhanced direct marketing and CRM to be transactional 'marketing-mix marketing by direct means' (see Figure 1). ${ }^{24}$

With the help of database technology, database marketing broadens and supports the entire marketing mix. Its main applications are segmentation, value analysis, controlling and reporting. After a thorough analysis of marketing practices, Coviello et al. come to the conclusion that database marketing is a more intense or closer form of transaction marketing, although they concede it to have a certain relational perspective. ${ }^{25,26}$ Database marketing implies the personalisation of communication, but mostly refrains from a more advanced customisation of both the offer and the customer-company relationship. Literature illustrates prevailing differences between database marketing and CRM in contemporary marketing. ${ }^{27,28}$ Academic research on database marketing, and the fact that it has survived the CRM-hype, confirms this impression..$^{29,30}$

Like database marketing, CRM is directly associated with IT usage. In fact, the term CRM is often identified with the respective information systems. Relationship marketing delivers the conceptual foundation which makes CRM a 'strategic bridge between IT and marketing strategies' (Figure 1). ${ }^{31}$ CRM is an example of relationship marketing that aims to retain customers, build lasting relationships and maximise customer value for the company. CRM strategy and operations differ significantly from the transactional marketing approach and often require sophisticated IT support. Direct and database marketing methods can be powerful instruments for achieving CRM goals, 


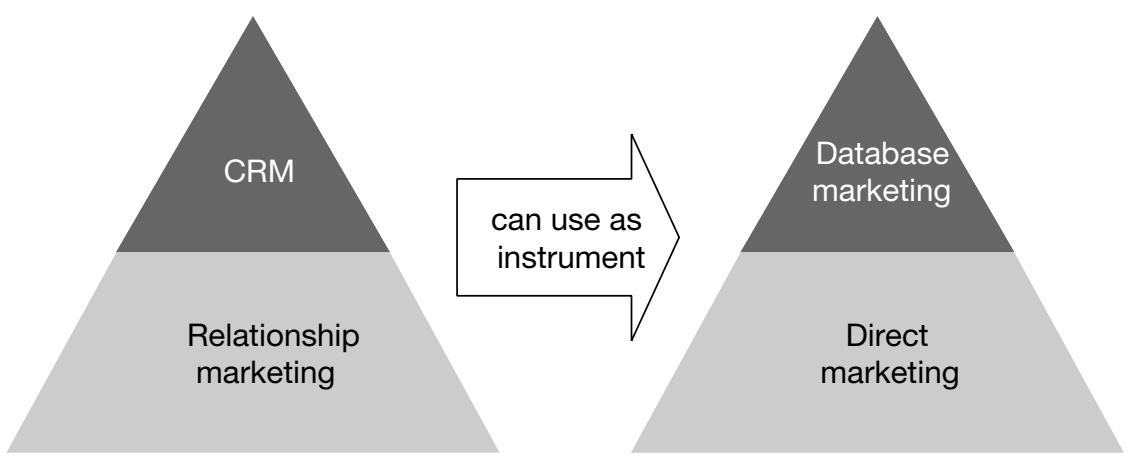

Figure 1: Conceptual foundations of database marketing and CRM

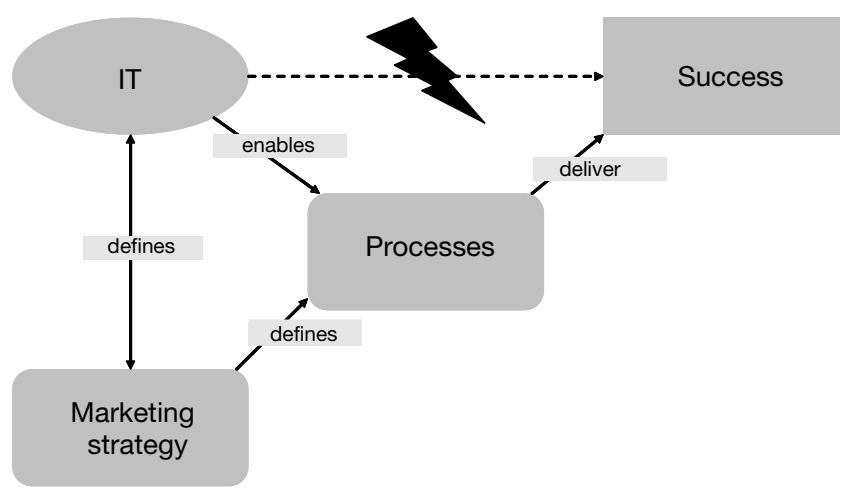

Figure 2: IT usage and marketing success (adapted from Wigand et al. ${ }^{37}$ )

but CRM is not an original sub-task of direct and database marketers. In contrast to database marketing, relationship marketing and CRM are mainly discussed at a strategic level, where collaborative relationships and customer retention are emphasised.

To ignore of the close linkage and fuzzy boundaries between database marketing and other information-intensive, IT-enhanced practices would be negligent; however, there is a significant difference between them, which can be derived from their historical development ${ }^{32,33}$ as well as from previously conducted research. ${ }^{34}$

\section{IT usage in marketing}

The different conceptual foundations of CRM and database marketing lead to corresponding complexities in their operationalisation, processes and IT representation within a company. To become successful, information systems, strategy and infrastructure have to be aligned with business and marketing strategy and processes. It is broadly agreed that investment in IT is not directly linked to an increase in company profit or, generally, labour productivity $(\text { see Figure } 2)^{35}$ yet its deployment appears mandatory, since it plays the major role in enabling state-of-the-art methods and processes in contemporary marketing. ${ }^{36}$

For the design of successful IT-enhanced marketing processes, there needs to be a fit ${ }^{38}$ between IT support and marketing requirements at the operational as well as at the strategic level. The above discussion of the two 
concepts of CRM and database marketing leads to the assumption that they are likely to have a different impact on management tasks to achieve this fit between IT and marketing perspectives.

Studies on organisational change and technology also back this assumption, with the proposition that technology can fulfil different roles within an organisation. $^{39,40}$ Orlikowski suggests three different roles: inertia, application and change. ${ }^{41}$ Inertia describes cases where technology is used in a limited way and the structural consequences are mainly the preservation of the status quo in organisation, processes and practices. Application denotes companies' deployment of technology 'to augment or refine their existing ways of doing things'. Finally, change represents those cases where companies use technology 'to substantially alter their existing way of doing things'. ${ }^{42}$

Database marketing, as it is interpreted here, deploys technology in terms of application. Traditional direct marketing tasks and measures are electronically enhanced and thereby shifted to a new level in quantity and quality. Certain features (eg marketing analytics) are added but do not induce a fundamental change in marketing strategy and operations. On the other hand, CRM often calls for such a strategic change and reorganisation of business processes to be successfully implemented. ${ }^{43}$ Technology is considered to play an active role in this process of change, which turns the focus on a high-level CRM into an example of Orlikowski's change enactment type of technology. Obviously, one cannot claim this distinction to be applicable for each implementation of database marketing and CRM, however, it nicely depicts the different consequences which the two concepts are claimed to have on the deployment of IT for marketing purposes.
No matter which approach is chosen, marketing and IT need to be coordinated. Management literature and streams of information systems (IS) research have extensively discussed the necessary fit between IT usage and business functions. Henderson and Venkatraman's original work on the alignment of IT and business strategies and operations lead to a stream of subsequent research. ${ }^{44,45}$ Their strategic alignment model ${ }^{46}$ adds dynamics to the static construct of fit and provides a framework for identifying the consequences of IT and information-intensive marketing strategies. ${ }^{47}$ It will be used to illustrate the different managerial implications of CRM and database marketing for a company's marketing efforts as a particular area for application.

\section{THE STRATEGIC ALIGNMENT MODEL}

Henderson and Venkatraman developed the strategic alignment model to describe the strategic choices facing managers when aligning business and IT. $^{48}$ This section will introduce the model and give brief examples of how it is used to describe different modes of management to achieve the desired fit between business and IT. It is built on the distinction between business and IT as separate areas of management concern. In addition, it distinguishes between an external view and an internal view. The external view focuses on the business arena of the competing firm, and encompasses the 'business strategy' and 'IT strategy' domains. ${ }^{49}$ The internal view looks at the institutional, organisational and infrastructural system that is installed to steer and enable the core business processes which make up the company's unique value proposition in the market. It includes the model's 


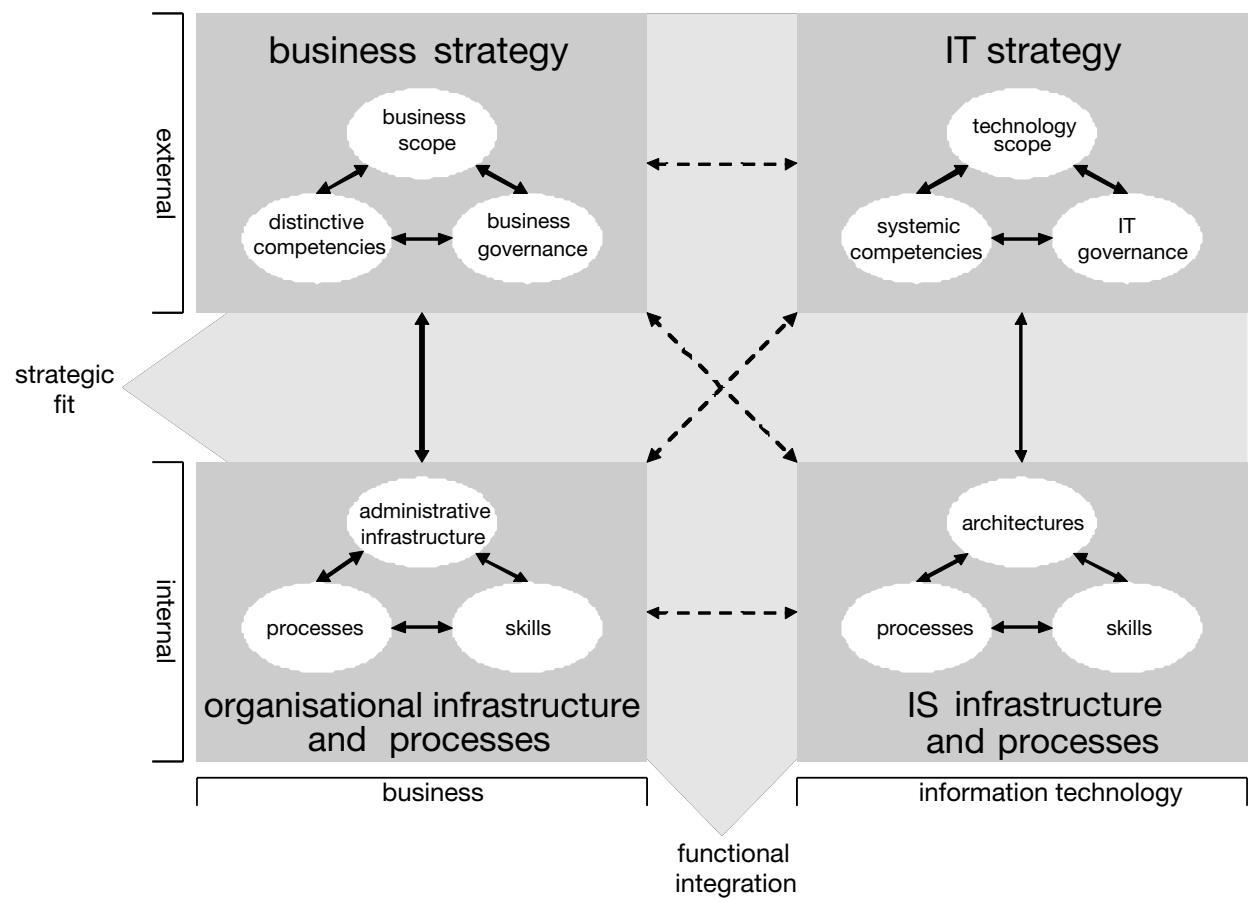

Figure 3: Henderson and Venkatraman's strategic alignment model ${ }^{51}$

remaining two domains 'organisational infrastructure and processes' and 'IS infrastructure and processes'. Each of the four domains has been further specified by a subset of three components (see Figure 3). ${ }^{50}$

A basic assumption of the model is that management's ability to achieve a strategic fit between the external and internal domains is linked to overall business success. ${ }^{52}$ Furthermore, the construct of fit is recognised to be dynamic and to be related to industry and market changes because of their implications for the continuing process of strategic and organisational development. ${ }^{53}$ Henderson and Venkatraman differentiate between business and IT as separate domains, they also postulate the need for horizontal inter-domain coordination - here called 'functional integration'. This describes the dictum of aligning choices made in the IT and business domains on the strategic as well as on the operational level. ${ }^{54}$ Eventually, what changed the way in which the IT domain was looked at from a strategic management perspective was the fact that both domains were equally considered to have the power to threaten or enhance each other, and to have a major impact on overall profitability.

The concept of strategic alignment calls for a balance among all four domains of the model. A bivariate fit between each of the domains appears hard to achieve because of potential internal inconsistencies and conflicts. ${ }^{55}$ Therefore, so called alignment perspectives have been developed which describe certain 'management styles' for linking business and IT strategies and operations. Each of the perspectives depicts the interplay between a set of originally three - domains and a characteristic direction or 'path of alignment'. ${ }^{56}$ They can be understood as 


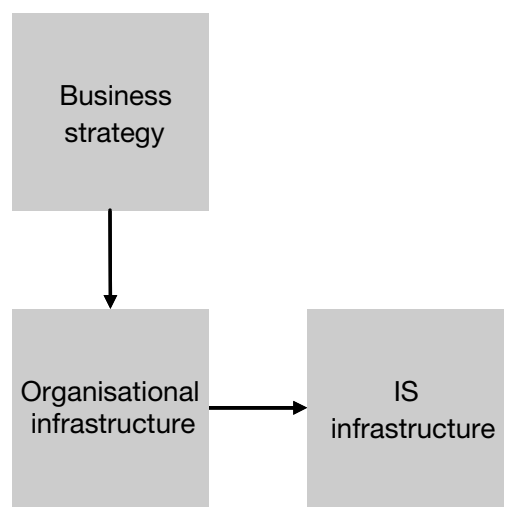

Strategy execution

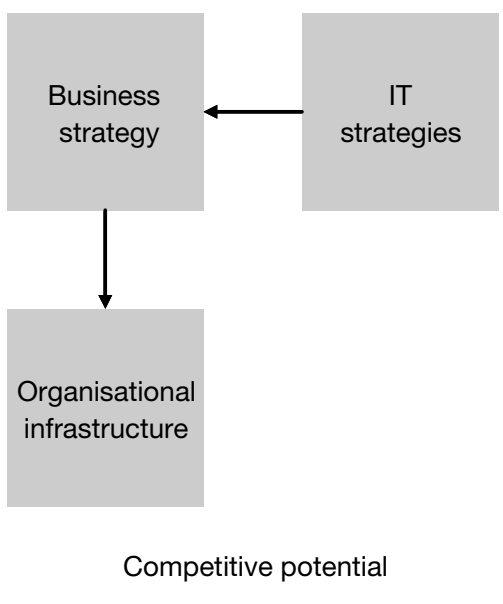

Figure 4: Alignment perspectives ${ }^{57,58}$

coordination processes with distinct foci, starting and end points.

Two of the four dominant alignment perspectives introduced by Henderson and Venkatraman are shown in Figure 4, which illustrates how the model is used to describe management practices.

Strategy execution depicts the alignment perspective which follows a traditional hierarchical view of strategic management. A company's business strategy primarily determines the design of the organisational infrastructure and business processes. In the second instance, the IT function is called upon to support and enable the previously specified changes in the internal business domain. Thus, top level management formulates the strategy and IT managers take part in the implementation process. The IT domain is not functionally integrated on the external strategic level and plays a rather passive role in reacting to business needs on an operational level..$^{59,60}$

The competitive potential perspective characterises an alignment process in which the role of the IT function differs substantially from the one described above. It focuses on the potential influence that innovative IT can have on the evolution of business strategies. The IT manager creates awareness of technological developments and potential business opportunities arising from their exploitation. ${ }^{61}$ This requires a continuous scanning of the IT market and a consequent assessment of the strategic value of innovations. Business management recognises the technology's potential and adopts it for a redefinition of business strategy — and, subsequently, processes and organisational infrastructure.

There has been extensive research on further applications of the strategic alignment model. ${ }^{62,63}$ Luftman and Papp identified additional alignment perspectives $^{64}$ and delivered empirical evidence for their existence by associating them with real world cases. Furthermore, perspectives have been combined to so-called 'fusions', which describe more complex processes with parallel alignment activities. ${ }^{65}$ The concept of strategic alignment has been applied to a multitude of business arenas and functions. These include e-commerce ${ }^{66,67}$ and networks. ${ }^{68}$ In particular, the strategic alignment model can be transformed to assess IT with 
regard to specific functions (eg marketing) within the enterprise. ${ }^{69,70} \mathrm{In}$ line with this recommendation alignment perspectives for the coordination of marketing and IT usage are proposed and described here.

\section{ALIGNING FOR DATABASE MARKETING AND CRM}

The conceptual distinction between database marketing and CRM brings about diverse requirements for IT support and enablement. Field reports on the concepts' implementation, and academic research on barriers to, drivers of or success factors for implementation show certain similarities but also differences. ${ }^{71,72,73}$ Research on strategic alignment enablers and inhibitors reveals results which give general insights ${ }^{74}$ but appears not to be sufficient to describe the specific challenges of IT strategic alignment in marketing and to examine the impact of different marketing concepts on IT usage. Yet, the need for a thorough alignment of IT and marketing activities is a well-accepted dictum. $^{75}$

In line with documented experiences with database marketing and CRM, and their conceptual differences, the author uses the strategic alignment model to define typical alignment perspectives for the management of database marketing and CRM initiatives. The findings are based on a review of the extensive literature dedicated to the two concepts. Two cases are used to further elaborate on the proposed perspectives. Both of them have also been subject to previous research on related topics.

\section{Database marketing}

Database marketing has previously been described as 'IT-enhanced direct marketing'. It evolved slowly with the need for more information processing capacity in traditional direct marketing and the mail order industry. ${ }^{76}$ Tapp defines direct and database marketing as subsets of the transaction marketing mix $^{77}$ and thus puts them on the level of marketing tactics and operations. ${ }^{78}$

The role of IT in database marketing has mostly been supportive and responsive to marketing needs, corresponding with an application role for IT following Orlikowski. ${ }^{79}$ The strategic impact of IT, eg by means of marketing or business strategy redefinition, has not been the focus of attention.

Although there are voices that call for a stronger position for database marketers in the strategy development process, ${ }^{80}$ the concept's transaction focus does not imply a large-scale shift in marketing strategy. When Roberts writes about the contents of a marketing database and their potential to support strategic decision-making, she rather talks about a by-product of database marketing which is the improved information base for marketing decisions. Furthermore, the author agrees with Tapp's view which refutes the claim that direct and database marketing should focus on customer relationship building. ${ }^{81}$ However, direct marketing measures, possibly supported by database marketing methods, can be a powerful tool for achieving superior relationship marketing goals (Figure 1).

The strategic alignment model offers a variety of perspectives on the management of IT-enabled practices or strategies. The nature of the database marketing concept and, to some extent, the result of academic research on barriers to and success factors for database marketing initiatives ${ }^{82,83}$ give clues that lead to the development of a path of alignment ${ }^{84}$ that companies are likely to have passed through (Figure 5).

The anchor in this alignment perspective is represented by the 


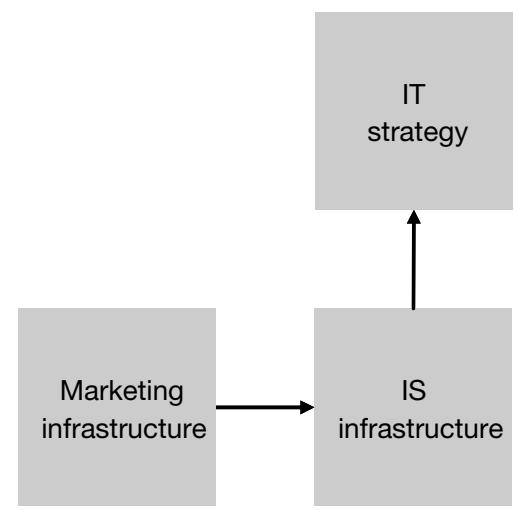

Figure 5: Typical alignment perspective of database marketing initiatives

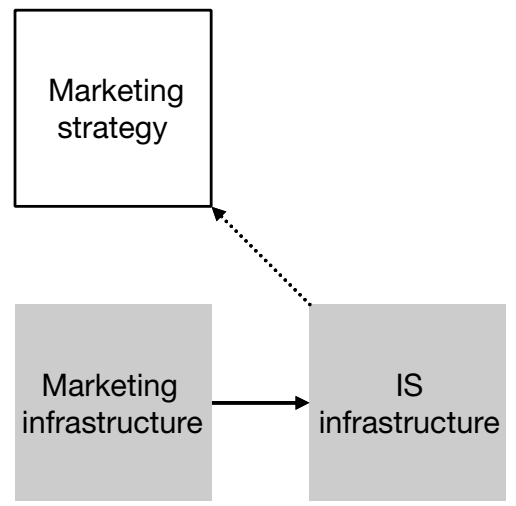

Figure 6: Strategic decision support potential of marketing database analytics

established organisational infrastructure, the processes and structure of marketing operations. The traditional transaction marketing approach is pursued. In the majority of cases, mass markets are served and direct marketing tools are used to foster sales. Established marketing processes, eg in the mail order industry, did not change fundamentally, but developed in quantity and quality. The growing demand for information processing capacity, and the simultaneous strong development of IT performance, leads to a substitution and enhancement of marketing tasks by automated means. Marketing needs shaped the IS infrastructure in order to achieve process improvements in effectiveness and efficiency.
The alignment perspective in Figure 5, which was originally named

'Organisation IT Infrastructure' by Papp ${ }^{85}$ shows the IT strategy as the third domain. The alignment path implies that a company's IT strategy is subsequently affected by changes made in the IS infrastructure. In this descriptive case of database marketing IT alignment, the existence and even the necessity of a separate IT strategy ${ }^{86}$ is questionable.

Here, the emphasis lies on the process of functional integration between marketing and IS infrastructure. An IT impact on marketing strategy is unlikely. Database marketing technology mainly supports established structures and processes.

The decision support potential of the 
marketing database content at a marketing strategy level (as described by Roberts ${ }^{87}$ ) is rather a secondary effect, and not part of the aims which were originally pursued with IT usage (Figure 6).

In the database marketing concept, IT has the ability to boost the efficiency of marketing processes but does not play a major role in marketing strategy development.

The IT usage of some companies in the mail order industry can be taken as an example of this type of alignment process. A case which has been subject to research in direct marketing is that of the German publisher Rhenania. Elsner, Krafft and Huchzermeier give a detailed introduction into the scenario. ${ }^{88}$

Rhenania uses its customer database to plan and conduct direct, distance selling activities for its specialised range of books. Its deployment of IT for marketing purposes is clearly dominated by a direct marketing approach. No thoughts of adaptation of strategy or dedication to relationship marketing have taken place. Rather, the information processing potential of the technology has been used to implement advanced models of marketing analysis and optimisation of campaign planning. ${ }^{89,90}$ Rhenania built upon its existing ways of direct selling — its marketing infrastructure in terms of established processes and marketing measures - and used database technology and analytical tools (IS infrastructure) to boost efficiency. Yet, as mentioned above, the domain most likely to be impacted in terms of a refined scope of activities due to augmented marketing analytics (Figure 6) is marketing strategy, rather than IT strategy.

\section{CRM}

Customer relationship management has been described as an instance of relationship marketing with a strong focus on enabling IT solutions. CRM software tools often promise to transfer the mechanisms for building close relationships between companies and their customers that are known from industrial marketing into consumer mass marketing. This introduces the need for extensive customer data acquisition, analysis and application.

The development of the CRM concept did not take place in a slow and gradual way as was the case of database marketing. It emerged rather quickly in the context of a discussed marketing paradigm shift towards relationship marketing and the rapid growth of IT applications and capacity. CRM has induced a large body of academic research dealing with the concept's clarification and possible success factors and barriers to implementation. ${ }^{91-96}$ Researchers and practitioners agree on the fact that CRM is too complex a concept to be realised by the mere implementation of a CRM software package. CRM requires the creation of a strategic fundamental which induces an often substantial redefinition of general business and marketing processes as well as underlying organisational structures. ${ }^{97,98}$ This awareness was the result of numerous bitter CRM failures in all kinds of industries, yet, they have provided case-based knowledge that helped to reveal a better picture of the management implications for companies that commit themselves to CRM.

The strategic alignment model can depict both cases: (1) the strategy driven, organisational change comprising CRM; and (2) the technology-focused CRM (Figure 7). In both cases, marketing strategy was defined as the starting point and anchor of the alignment process. However, marketing leaders take different roles in the perspectives the author calls 'marketing strategy execution' 


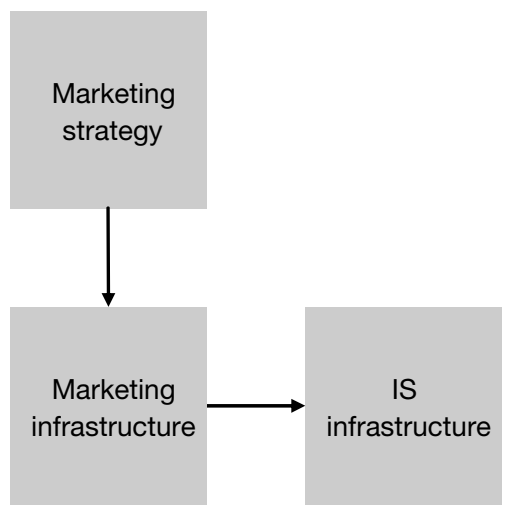

Marketing strategy execution

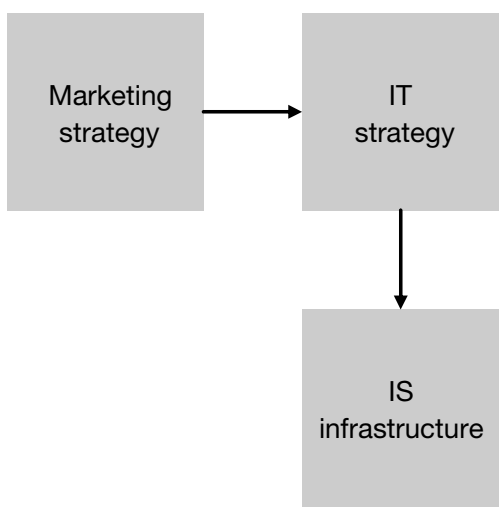

CRM technology potential

Figure 7: Alignment perspectives for two different CRM implementation scenarios

and 'CRM technology potential'.

The latter represents those cases which became the main cause for criticism in the CRM discussion. Marketing executives identified CRM as a critical strategic issue and decided to implement it possibly without in-depth knowledge of the relevant steps to take and the aspects to consider. First and foremost, they might have cherished the illusion that CRM could be installed successfully by simply choosing the adequate software suite and giving staff access to the integrated customer database. Here, the functional integration between marketing and IT strategy is flawed. IT executives are entrusted with the CRM project which is thereby degraded into being a technological rather than a business challenge. ${ }^{99,100}$ CRM projects with a history similar to this alignment path are likely to lead to problems, according to insights of both scholars and practitioners. Changes made in the IS infrastructure result from pursuing CRM implementation solely as an IT project. The consequences might include the misfit between marketing needs and IT solutions, eg due to an under-rating of strategic and organisational marketing issues.

The 'marketing strategy execution' perspective (Figure 7) presumes a different alignment path in managing CRM projects. Marketing executives formulate their intention to implement CRM. Marketing personnel are assigned the task of creating or redesigning the processes and organisational structures necessary to achieve the goals associated with CRM implementation. According to Henderson and Venkatraman's assumptions, ${ }^{101}$ a strategic fit between marketing strategy and infrastructure has to be obtained. The substantial change in marketing infrastructure creates new requirements for technological support. The IS infrastructure is (passively) adapted to meet these requirements. For successful alignment, marketing and IS infrastructure ought to be functionally integrated.

This alignment path is consistent with more of the currently available body of experience and knowledge of CRM success. The emphasis on a marketing strategic basis and adequate organisational and cultural change is represented. By contrast with the 'CRM technology potential case, however, issues concerning IT and the strategic impact of information systems are under-rated. The concentration on marketing needs can 


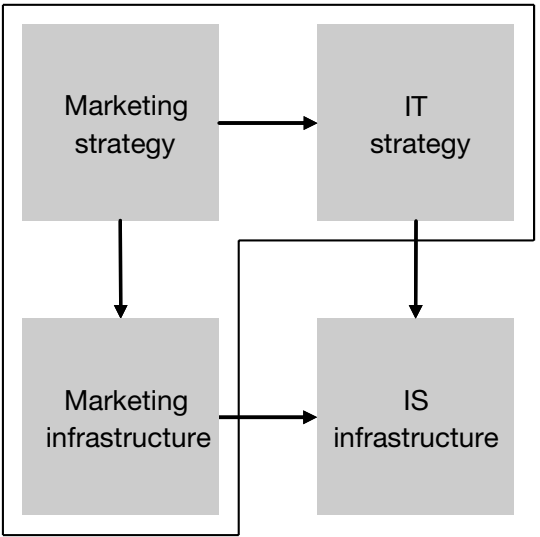

IT infrastructure fusion

Figure 8: Fusion perspective on marketing-IT alignment for CRM

hinder the adoption of innovative technology which would maybe enable the company to follow radically new ways of serving customers, building lasting relationships and loyalty.

IT innovations can either be an ingredient or a catalyst ${ }^{50}$ of strategic change in marketing. A steady exchange of ideas and visions on the strategic, as well as the operational, level is needed to ensure functional integration and strategic fit between any of the four domains used in the strategic alignment model.

Current research and experiences in CRM prepare the ground for the combination of the two simple perspectives discussed above. According to Papp, ${ }^{103}$ the resulting fusion - namely 'IT infrastructure fusion' - potentially accumulates the benefits of each single perspective and can create a weighted relationship between marketing and IT issues in CRM implementation (Figure 8).

Again marketing strategy is the anchor and stimulus of the CRM initiative. This is in line with the prevailing opinion that the consideration of marketing strategy is the basis of successful CRM implementations. ${ }^{106}$ The joint efforts of IT and marketing executives in strategy formulation and the focus on organisational redesign rather than in technological excess is likely to lead to crucial functional integration at the organisational level without disregarding IT potential. In fact, this fusion of perspectives illustrates, in a condensed way, what has been learned about CRM implementation from the past.

The British retailer, Tesco, is a well documented case which could serve as an example for the fusion perspective. Tesco committed itself to a relationship marketing approach by focusing on earning customer loyalty. The 'Clubcard' loyalty scheme is highly successful and gave Tesco access to individual customer data which are used for advanced marketing analytics and personalisation and individualisation of marketing communications. Furthermore, Tesco's practices have increasingly tended towards an interaction-based marketing approach $^{105}$ when it launched its even more successful tesco.com internet branch, which has numerous value-adding service offers. ${ }^{106,107}$ Tesco started out with a modification of its marketing strategy ${ }^{108,109}$ and understood the subsequent alignment process to be one of continuous improvement and 
learning. ${ }^{110}$ IT has been deployed for improving efficiency and enabling advanced operations. It also impacted Tesco on a strategic level when the electronic marketing channel was added. Thus Tesco is likely to have gone through a more balanced process of aligning marketing and IT. Marketing strategy is the ultimate anchor, but it is not likely that the use of IT is merely determined by marketing infrastructure needs. In fact, IT seems to have been granted a more active and influential role on the external, strategic level, as well as on the internal, operational level.

\section{CONCLUSIONS AND FURTHER THOUGHTS}

The results of this work are twofold. First, the application of the strategic alignment model to the concepts of database marketing and CRM adds to the discussion on their differences and similarities as well as supporting the general need for a theoretical distinction. The discrepancies have been shown and used to explain how companies adopted one or the other. Although the argument is made at abstract level, the author believes that it is possible to pinpoint several aspects which have previously been the subject of academic research. In particular, the strategic alignment model is valuable for displaying the role of IT and IT executives in diverse CRM and database marketing initiatives. Two cases were chosen to illustrate the proposed alignment perspectives. Their discussion indicates the usefulness of the strategic alignment model for descriptive or explanatory ex-post analyses which can be used for pattern matching or theory building purposes.

Secondly, the strategic alignment model can unfold its heuristic value for managerial aspects of the use of technology in marketing. It can be used as framework for task analysis in respective projects. There is a large body of research in the field of IS in the alignment of business and IT, but a thorough translation and extension of general insights into specific domains like marketing has not yet taken place. Henderson's and Venkatraman's model can integrate numerous findings from real world cases and academic research and gives a macro view on the steps to take in marketing-IT alignment. It once more draws attention to the importance of boundary spanning activities inside a company. Functional integration of marketing and IT - the penetration of organisations with IT competence then becomes an imperative.

\section{References}

1 Brady, M., Saren, M. and Tzokas, N. (2002) 'Integrating information technology into marketing practice - The IT reality of contemporary marketing practice', Journal of Marketing Management, Vol. 18, No. 5/6, pp. 555-577.

2 Coviello, N. E., Milley, R. and Marcolin, B. (2001) 'Understanding IT-enabled interactivity in contemporary marketing', Journal of Interactive Marketing, Vol. 15, No. 4, pp. 18-33.

3 Petrison, L. A., Blattberg, R. C. and Wang, P. (1997) 'Database marketing: Past, present and future', Journal of Direct Marketing, Vol. 11, No. 4, pp. 109-125.

4 Grönroos, C. (1994) 'From marketing mix to relationship marketing: Towards a paradigm shift in marketing', Management Decision, Vol. 32, No. 2, pp. 4-20.

5 Blattberg, R. C. and Deighton, J. (1991) 'Interactive marketing: Exploiting the age of addressability', Sloan Management Review, Vol. 33, No. 1, pp. 5-14.

6 Fletcher, K., Wheeler, C. and Wright, J. (1992) 'Success in database marketing: Some crucial factors', Marketing Intelligence \& Planning, Vol. 10, No. 6, pp. 18-23.

7 Ling, R. and Yen, D. C. (2001) 'Customer relationship management: An analysis framework and implementation strategies', Journal of Computer Information Systems, Vol. 41, No. 3, pp. 82-97.

8 Rigby, D. K., Reichheld, F. F. and Schefter, P. (2002) 'Avoid the four perils of CRM', Harvard Business Review, Vol. 80, No. 2, pp. 101-109.

9 Kotorov, R. P. (2002) 'Ubiquitous organization: organizational design for e-CRM', Business 
Process Management Journal, Vol. 8, No. 2, pp. 218-232.

10 McKim, B. (2002) 'The differences between CRM and database marketing', Journal of Database Marketing, Vol. 9, No. 4, pp. 371-375.

11 Nairn, A. (2002) 'CRM: Helpful or full of hype?’ Journal of Database Marketing, Vol. 9, No. 4, pp. 376-382.

12 McKim (2002) op cit.

13 Hughes, A. M. (2002) 'The mirage of CRM', Journal of Database Marketing, Vol. 9, No. 2, pp. 102-104.

14 Patron, M. (2002) 'If database marketing was so good, why is CRM so bad?' Journal of Database Marketing, Vol. 10, No. 2, pp. 102-103.

15 Tapp, A. (2001) 'The strategic value of direct marketing: What are we good at? Part 1', Journal of Database Marketing, Vol. 9, No. 1, pp. 9-15.

16 Brady et al. (2002) op cit.

17 Leverick, F., Littler, D., Wilson, D. and Bruce, M. (1997) 'The role of IT in the reshaping of marketing', Journal of Marketing Practice, Vol. 3, No. 2, pp. 87-106.

18 Brady et al. (2002) op cit.

19 Luftman, J. N. (2003) 'Strategic alignment as a process' in: Luftman, J. N. (ed.), 'Competing in the information age: Align in the Sand', 2nd edition, Oxford University Press, Oxford, UK, pp. 381-394.

20 Brady, M. (2003) 'Managing information technology assimilation: A marketing perspective', Irish Journal of Management, Vol. 24, No. 1, pp. 125-138.

21 Henderson, J. C. and Venkatraman, N. (1993) 'Strategic alignment: Leveraging information technology for transforming organizations', IBM Systems Journal, Vol. 32, No. 1, pp. 4-16.

22 Roberts, M. L. (1997) 'Expanding the role of the direct marketing database', Journal of Direct Marketing, Vol. 11, No. 4, pp. 26-35.

23 Schoenbachler, D. D., Gordon, G. L., Foley, D. and Spellman, L. (1997) 'Understanding consumer database marketing', Journal of Consumer Marketing, Vol. 14, No. 1, pp. 5-19.

24 Tapp (2001) op cit.

25 Coviello, N. E., Brodie, R. J., Danaher, P. J. and Johnston, W. J. (2002) 'How firms relate to their markets: An empirical examination of contemporary marketing practices', Journal of Marketing, Vol. 66, No. 3, pp. 33-46.

26 Coviello, N. E., Brodie, R. J and Munro, H. J. (1997) 'Understanding comtemporary marketing: Development of a classification scheme', Journal of Marketing Management, Vol. 13, No. 6, pp. 501-522.

27 Coviello et al. (2002) op cit.

28 Coviello et al. (1997) op cit.

29 McKim (2002) op cit.

30 Tapp (2001) op cit.

31 Ryals, L. and Payne, A. (2001) 'Customer relationship management in financial services: towards information-enabled relationship marketing', Journal of Strategic Marketing, Vol. 9, No. 1, pp. 3-27.

32 Petrison et al. (1997) op cit.

33 Grönroos (1994) op cit.

34 Coviello et al. (2001) op cit.

35 Wigand, R. T., Picot, A. and Reichwald, R. (1997) 'Information, organization and management: Expanding markets and corporate boundaries', Wiley, New York, NY.

36 Coviello et al. (2001) op cit.

37 Wigand et al. (1997) op cit.

38 Venkatraman, N. (1989) 'The concept of fit in strategy research', Academy of Management Review, Vol. 14, No. 3, pp. 423-444.

39 Coviello et al. (2001) op cit.

40 Orlikowski, W. J. (2000) 'Using technology and constituting structures: A practice lens for studying technology in organizations', Organization Science, Vol. 11, No. 4, pp. 404428.

41 Ibid.

42 Ibid.

43 Rigby, D. K, Reichheld, F. and Dawson, C. (2003) 'Winning customer loyalty is the key to a winning CRM strategy', Ivey Business Journal, Vol. 67, No. 4, pp. 1-5.

44 Henderson and VEnkatraman (1993) op cit. 45 Henderson, J. C, Venkatraman, N. and Oldach, S. (1996) 'Aligning business and IT strategies', in: Luftman, J. N. (ed.), 'Competing in the information age: Strategic alignment in practice', Oxford University Press, pp. 21-42.

46 Henderson and Venkatraman (1993) op cit.

47 Glazer, R. (1999) 'Winning in smart markets', Sloan Management Review, Vol. 40, No. 4, pp. 59-69.

48 Henderson and Venkatraman (1993) op cit. 49 Ibid.

50 Luftman, J. N. (1999) 'Glossary of strategic alignment terminology', in: Luftman, J. N. (ed.), 'Competing in the information age: Strategic alignment in practice', Oxford University Press, Oxford, UK, pp. 404-411.

51 Henderson and Venkatraman (1993) op cit. 52 Henderson et al. (1996) op cit.

53 Henderson and Venkatraman (1993) op cit.

54 Nelson, M. R. (2001) 'Alignment through cross-frunctional integration', in: Papp, R. (ed.), 'Strategic information technology: Opportunities for competitive advantage', Idea Group, Hershey, PA, pp. 40-55.

55 Henderson and Venkatraman (1993) op cit. 56 Luftman (1996) op cit.

57 Henderson and Venkatraman (1993) op cit.

58 Papp, R. (2001) 'Introduction to strategic alignment', in: Papp, R. (ed.), 'Strategic information technology: Opportunities for competitive advantage', Idea Group, Hershey, PA, pp. 1-24.

59 Henderson and Venkatraman (1993) op cit. 60 Papp (2001) op cit.

61 Ibid. 
62 Luftman, J. N. (1996) 'Competing in the information age: Strategic alignment in practice', Oxford University Press, New York, NY.

63 Luftman, J. N. (2003) 'Competing in the information age: Align in the sand', 2nd edition, Oxford University Press, Oxford, UK.

64 Papp, R. and Luftman, J. N. (1995) 'Business and IT strategy alignment: New perspectives and assessments', in: 'Proceedings of the AIS inaugural Americas conference on information systems', August 25-27, Pittsburgh, PA.

65 Papp (2001) op cit.

66 Nakayama, M. (2001) 'Aligning IT resources for e-commerce', in: Papp, R. (ed.), 'Strategic information technology: Opportunities for competitive advantage', Idea Group, Hershey, PA, pp. 185-199.

67 Bauer, C. (2001) 'Strategic alignment for electronic commerce' in: Papp, R. (ed.), 'Strategic information technology: Opportunities for competitive advantage, Idea Group, Hershey, PA, pp. 258-272.

68 Luftman, J. N. (2003) 'IT governance' in: Luftman, J. N. (ed.) 'Competing in the information age: Align in the sand', 2nd edition, Oxford University Press, Oxford, Uk, pp. 161-190.

69 Luftman (2003) op cit.

70 Luftman (1996) op cit.

71 Fletcher et al. (1992) op cit.

72 Desai, C., Fletcher, K. and Wright, G. (2001) 'Drivers in the adoption and sophistication of database marketing in the services sector', The Service Industries Journal, Vol. 21, No. 4, pp. 1732.

73 Leverick, F., Littler, D., Bruce, M. and Wilson, D. (1998) 'Using information technology effectively: A study of marketing installations', Journal of Marketing Management, Vol. 14, No. 8, pp. 927-962.

74 Luftman, J. N. and Brier, T. (1999) 'Achieving and sustaining business-IT alignment', California Management Review, Vol. 42, No. 1, pp. 109-122.

75 Lewington, J., de Chernatory, L. and Brown, A. (1996) 'Harnessing the power of database marketing', Journal of Marketing Management, Vol. 12, No. 4, pp. 329-346.

76 Petrison et al. (1997) op cit.

77 Tapp (2001) op cit.

78 Cooke, S. (1994) 'Database marketing: Strategy or tactical tool? Marketing Intelligence \& Planning, Vol. 12, No. 6, pp. 4-7.

79 Orlikowski (2000) op cit.

80 Roberts (1997) op cit.

81 Tapp (2001) op cit.

82 Fletcher, K. and Wright, G. (1995)

'Organizational, strategic and technical barriers to successful implementation of database marketing',
International Journal of Information Management, Vol. 15, No. 2, pp. 115-126.

83 Keen, P. G. W. (1996) 'Do you need an IT strategy?' in: Luftman, J. N. (ed.) 'Competing in the information age: Strategic alignment in practice', Oxford University Press, Oxford, UK, pp. 137- 178.

84 Papp (2001) op cit.

85 Ibid.

86 Keen (1996) op cit.

87 Roberts (1997) op cit.

88 Elsner, R., Krafft, M. and Huchzermeier, A. (2003) 'Optimizing Rhenania's mail-order business through dynamic multilevel modeling (DMLM)', Interfaces, Vol. 33, No. 1, pp. 50-66. 89 Ibid.

90 Elsner, R., Krafft, M. and Huchzermeier, A. (2004) 'Optimizing Rhenania's direct marketing business through dynamic multilevel modeling (DMLM) in a multicatalog-brand environment', Marketing Science, Vol. 23, No. 2, pp. 192-207.

91 Ling and Yen (2001) op cit.

92 Rigby et al. (2002) op cit.

93 Coviello et al. (2002) op cit.

94 Coviello et al. (1997) op cit.

95 Ryals and Payne (2001) op cit.

96 Wilson, H., Daniel, E. and McDonald, M. (2002)

'Factors for success in customer relationship management (CRM) systems', Journal of Marketing Management, Vol. 18, No. 1/2, pp. 193-219.

97 Rigby et al. (2002) op cit.

98 Kotorov (2002) op cit.

99 Rigby et al. (2002) op cit.

100 Ross, J. W. and Weill, P. (2002) 'Six IT decisions your IT people shouldn't make', Harvard Business Review, Vol. 80, No. 11, pp. 84-91.

101 Henderson and Venkatraman (1993) op cit.

102 Markus, M. L. (2004) 'Technochange management: Using IT to drive organizational change', Journal of Information Technology, Vol. 19, No. 1, pp. 4-20.

103 Papp and Luftman (1995) op cit.

104 Rigby et al. (2003) op cit.

105 Coviello et al. (1997) op cit.

106 Bevan, J. and Murphy, R. (2001) 'The nature of value created by UK online grocery retailers', International Journal of Consumer Studies, Vol. 25, No. 4, pp. 279-289.

107 Seybold, P. B. (2001) 'Get inside the lives of your customers', Harvard Business Review, Vol. 79, No. 5, pp. 81-89.

108 Maddali, P. (2003) 'Tesco in 2003', Global CEO, Vol 3, No. 6, pp. 65-79.

109 Mason, T. (1998) 'The best shopping trip? How Tesco keeps the customer satisfied', International Journal of Market Research, Vol. 40, No. 1, pp. 5-12.

110 Child, P. N. (2002) 'Taking Tesco global', McKinsey Quarterly, No. 3, pp. 134-144. 